\title{
Article 5
}

\section{Developing Cyber-bullying Knowledge and Awareness Instrument (CBKAi) to Measure Knowledge and Perceived Awareness Towards Cyber-bullying among Adolescents}

\author{
Nadia Abdul Wahab \\ Faculty of Computer and Mathematical Sciences \\ Universiti Teknologi MARA Perlis Branch, Malaysia \\ Wan Ahmad Jaafar Wan Yahaya \\ Centre For Instructional Technology \& Multimedia \\ Universiti Sains Malaysia, Penang, Malaysia
}

\begin{abstract}
In this study, the researcher developed an instrument to measure the level of adolescents 'knowledge and perceived awareness on cyber-bullying. This instrument is known as the Cyber-bullying Knowledge and Awareness Instrument (CBKAi).Content validity was performed to determine whether the instrument comprises a representative sample of the behaviour domain to be measured. CBKAi was validated by a senior lecturer from a public university who is also an expert in cyber-bullying and also two secondary school counsellors. Apart from that, CBKAi was also tested for its reliability with 30 respondents. The Cronbach's alpha internal consistency reliability coefficient for the instrument is 0.919 for items that are related to knowledge and 0.810 for items that are related for perceived awareness. The statistics show that CBKAi is a reliable instrument to be utilized to measure knowledge and perceived awareness towards cyber-bullying among adolescents.
\end{abstract}

Keywords:validity, reliability, cyber-bullying

\section{Introduction}

The issue of bullying has long been a topic of discussion amongst educationists, academicians and researchers. Smith and Thompson (1991) defined bullying as a set of conduct that is done intentionally and causes physical and psychological harm to the receiver. According to Kowalski and Limber (2007), as technology evolves, bullying has also evolved to include electronically based forms of aggression. Now, there is a new channel through which someone is bullied, and that is through the Internet and other telecommunication devices like cell phones. This form of bullying is known as cyber-bullying(Kowalski and Limber, 2007). Like traditional bullying, cyber-bullying victims are also exposed to the negative consequences of this phenomenon. They might isolate themselves especially from school activities, become stressed as well as ill and possibly contemplate suicide (Willard, 2007).

Knowledge and awareness of cyber-bullying is still looked upon lightly by the society (Nadia and Wan Ahmad Jaafar, 2012). What the public are not aware of is the threat of cyber-bullying that can be compared to an illness that will destroy the society especially, adolescents. A national survey in 2013 also showed that adolescents' awareness of cyber-bullying were still low (CyberSAFE in Schools 2013 Survey, 2013).

Even though laws such as the Computer Crimes Act 1997 and the Communications and Multimedia Act 1998 have been enacted in Malaysia, knowledge and awareness of the public with regards to cyber-bullying remain low. There are many in the society who do not know or 
do not consider cyber-bullying to be a serious matter. This is evident as very few cases have been reported to the authorities (Topçu, Erdur-Baker and Capa-Aydin, 2008).

In this study, the researcher developed an instrument to measure the level of adolescents'knowledge and perceived awareness on cyber-bullying. This instrument is known as the Cyber-bullying Knowledge and Awareness Instrument (CBKAi). The instrument could be utilized to measure the level of knowledge and perceived awareness towards cyber-bullying among adolescents. Berne, et.al (2012) who had conducted a systematic review on forty-four (44) cyber-bullying instruments found that there were no instrument that had been specifically developed to measure the level of adolescents' knowledge and awareness on cyber-bullying.

From literature review, it was found that most instruments that had been developed were more structured towards exploring how far adolescents were involved in cyber-bullying activities, either as victims, bullies or bystanders; for instance, the instrument developed by Erdur-Baker (2010). Additionally, there were several instruments that studied about the coping strategies of cyber-bullying, such as that developed by Li (2008) and the emotional or behavioural impact of being cyber-bullied by Beran and Li (2005).

\section{Development of CBKAi}

The instrument to be discussed in this paper consists of thirty (30) questionnaires, which intended to measure the level of adolescents'knowledge and perceived awareness on cyberbullying.CBKAi was divided into three different sections. Section 1 of the instrument consisted of demographic variables, whereas Sections 2 to 3 dealt with knowledge and perceived awareness, respectively. The demographic variables included age, gender, race, and also whether the respondent has a smart phone and internet access at home.

In order to construct the items that measure the level of adolescents' knowledge on cyberbullying, the researcher referred to the findings of Willard (2007), Dilmac (2009) and Kowalski and Limber (2007).In developing the items that measure the level of perceived awareness of adolescents on cyber-bullying, the researcher referred to several studies that were conducted by cyber-bullying expert such as Hinduja and Patchin (2006) and Beran and Li (2005). Furthermore, the researcher also referred to several sources such as guidelines on cyberbullying that were outlined by Willard (2005).

In CBKAi, there are 12 items that have been utilized to access the level of knowledge that the adolescents possess in understanding the characteristics, method and the nature of cyberbullying. The respondents need to determine whether each action could lead to cyber-bullying or resembles cyber-bullying act or not. All questions related to knowledge had two possible options i.e., "Yes" and "No". Below are some examples of questions for knowledge of cyberbullying:

i. Sending or posting untrue statements about a person to other people,

ii. Sending or posting material about a person that contains sensitive, private, or embarrassing information (e.g. private messages or images),

iii. Creating a fake account in social media just for fun,

iv. Intentionally exclude a person from an online group (e.g. Whatsapp group) and

v. Sharing social media password with a best friend.

vi. Pretending to be someone else online in order to solicit or post personal or false information about someone else. 
Another 18 items has been used to measure the level of perceived awareness that the students have on the consequences of cyber-bullying, coping strategy of cyber-bullying and steps to prevent the growth of cyber-bullying among adolescents.All questions related to perceived awareness had five possible options i.e., "Strongly Unaware", "Unaware", "I am not sure", "Aware" and "Strongly Aware". Examples of questions for perceived awareness of cyberbullying are as below:

i. Do you aware that you should keep evidence of cyber-bullying (e.g screen shot) and you could use this evidence to report cyber-bullying incidents?

ii. Do you aware cyber-bullying often stop if you do not respond to the cyber-bully?

iii. Do you aware that you could block the person who is cyber-bullying?

iv. Do you aware that most victims of cyber-bullying have the tendency to commit suicide?

v. Do you aware that if you have been a witness to cyber-bullying incidents, you should report the cyber-bullying to someone who can help the victim?

\section{Validity of CBKAi}

As suggested by Anastasi and Urbina (1997), content validity is performed to determine whether it comprises a representative sample of the behaviour domain to be measured. Foxcroft, Paterson, Le Roux and Herbst (2004), stated that the content validity could be improved by using a panel of experts to review the test specifications and the selection of items.CBKAi was developed by the researcher and then validated by a senior lecturer from a public university who is also an expert in cyber-bullying. It was also validated by two secondary school counsellors. These experts reviewed the items from the instrument and commented whether the items comprise of a representative sample of the domain.

The first draft of the instrument was presented to the experts, who judged on the redundancy, content validity, clarity, and readability. The experts evaluated the instrument providing several useful comments. Modifications made to the first draft of the instrument based on the experts' comments. These comments involved rewording, rearranging, deleting, as well as adding items, examples, definitions, and/or easier terms.

\section{Reliability of CBKAi}

Reliability is defined as "the consistency with which a measuring instrument yields a certain results when the entity being measured has not changed" (Leedy and Ormrod, 2005). Reliability can be established in four different ways: equivalency, stability, inter-rater, and internal consistency (Carmines and Zeller, 1979). Cronbach's alpha is the ideal statistic for estimating the internal consistency reliability of a measure (Cohen and Swerdlik, 2005).

CBKAi was tested for its reliability with 30 respondents. The analysis was done using SPSS ver. 22. The Cronbach's alpha internal consistency reliability coefficient for the instrument is 0.919 (Table 1) for items that are related to knowledge.

Table 1 Reliability Statistics for Items Related to Knowledge

\begin{tabular}{|c|c|c|}
\hline Cronbach's Alpha & \multicolumn{1}{c|}{$\begin{array}{c}\text { Cronbach's Alpha Based on } \\
\text { Standardized Items }\end{array}$} & N of Items \\
\hline .919 & .912 & 12 \\
\hline
\end{tabular}


The Cronbach's alpha internal consistency reliability coefficient for the instrument is 0.810 (Table 2) for items that are related for perceived awareness.

Table 2 Reliability Statistics for Items Related to Perceived Awareness

\begin{tabular}{|c|c|c|}
\hline Cronbach's Alpha & $\begin{array}{c}\text { Cronbach's Alpha Based on } \\
\text { Standardized Items }\end{array}$ & N of Items \\
\hline .810 & .810 & 18 \\
\hline
\end{tabular}

The Cronbach's alpha internal consistency reliability coefficient values in Table 1 and Table 2 show that CBKAi is a reliable instrument to be utilized in order to measure the level of adolescents'knowledge and perceived awareness on cyber-bullying.

\section{Conclusion}

In this study the researcher developed and validated an instrument, CBKAi, which consists of thirty (30) questionnaires, to measure the level of knowledge and perceived awareness on cyber-bullying among adolescents. The instrument was validated by a panel who are experts in cyber-bullying. This instrument was also tested for its reliability with 30 respondents. The Cronbach's alpha internal consistency reliability coefficient values from the reliability test show that CBKAi is a reliable instrument to be utilized to measure knowledge and perceived awareness towards cyber-bullying among adolescents.

\section{References}

Anastasi, A., \& Urbina, S. (1997). Validity. Psychological Testing: Upper Saddle River (NJ): Prentice Hall.

Beran, T., \& Li, Q. (2005). Cyber-harassment: A study of a new method for an old behavior. journal of educational Computing Research, 32(3), 265-277.

Berne, S., Frisén, A., Schultze-Krumbholz, A., Scheithauer, H., Naruskov, K., Luik, P., et al. (2013). Cyberbullying assessment instruments: A systematic review. Aggression and violent behavior, 18(2), 320-334.

Carmines, E. G., \& Zeller, R. A. (1979).Reliability and validity assessment (Vol. 17): Sage.

Cohen, R., \&Swerdlik, M. (2005). Psychological testing and measurement: An introduction to tests and measurement. McGraw-Hill, Boston, MA.

CyberSAFE in Schools 2013 Survey. (2013).

Dılmaç, B. (2009). Psychological Needs as a Predictor of Cyber bullying: a Preliminary Report on College Students. Educational Sciences: Theory \& Practice, 9(3).

Foxcroft, C., Paterson, H., Le Roux, N., \&Herbst, D. (2004). Psychological assessment in South Africa: A needs analysis. The test usage patterns and needs of psychological assessment practitioners.

Kowalski, R. M., \& Limber, S. P. (2007).Electronic bullying among middle school students.Journal of Adolescent Health, 41(6), S22-S30.

Leedy, P. D., \&Ormrod, J. E. (2005).Practical research: Pearson Merrill Prentice Hall Columbus, $\mathrm{OH}$.

Li, Q. (2008). A cross-cultural comparison of adolescents' experience related to cyberbullying. Educational Research, 50(3), 223-234.

Patchin, J. W., \&Hinduja, S. (2006). Bullies move beyond the schoolyard a preliminary look at cyberbullying. Youth violence and juvenile justice, 4(2), 148-169.

Smith, \& Thompson, D. (1991).Practical approaches to bullying: David Fulton Publish.

Topcu, Ç.,\&Erdur-Baker, Ö. (2010). The revised cyber bullying inventory (RCBI): Validity and reliability studies. Procedia-Social and Behavioral Sciences, 5, 660-664. 
Topçu, C., Erdur-Baker, Ö.,\&Capa-Aydin, Y. (2008). Examination of cyberbullying experiences among Turkish students from different school types. CyberPsychology\& Behavior, 11(6), 643-648.

Wahab, N. A., \&Yahaya, W. A. J. W. (2012).A Preliminary Investigation: Feasibility of WebBased Multimedia Learning (WBML) in Raising Awareness of Cyber Bullying. Paper presented at the Proceeding of the Post Graduate National Mini Conference, Sungai Petani, Kedah.

Willard, N. (2005). Educator's Guide to Cyberbullying Addressing the Harm Caused by Online Social Cruelty. Retrieved July, 26, 2012, from http://www.asdk12.org/middlelink/avb/bully topics/educatorsguide_cyberbullying.pdf

Willard, N. E. (2007). Cyber-safe kids, cyber-savvy teens : helping young people learn to use the internet safely and responsibly: San Francisco, Calif. : Jossey-Bass, c2007 (Norwood, Mass. : Books24x7.com [generator]). 